\title{
POLITICAL PARTICIPATION OF ISLAMIC PARTIES
}

\author{
Nasrullah Muhammad Nur \\ Faculty Dakwah dan Humaniora, \\ Sultan Muhammad Syafiuddin Sambas Institute of Islamic Religion (IAIS), Indonesia \\ (Email: Nasrh.006@gmail.com)
}

Accepted date: 13-03-2018

Published date: 11-07-2019

To cite this document: Nur, N. M. (2019). Political Participation of Islamic Parties. International Journal of Law, Government, and Communication, 4(15), 166-173.

DOI: $10.35631 /$ ijlgc.4150017

\begin{abstract}
The discussion on the role of Islamic political parties in Muslim-majority countries is a hot conversation not only among the political elite but also in the lower society. Is a political party based on Islam is right to fight for the rights of Muslims or just a mere mask behind the Religion alias in the name of Islam in order to achieve certain goals. This article highlights the issue of how the role of Islamic political parties or the participation of Islamic parties in building the welfare of the people mandated to them especially when they are in power. How can an Islamic party gain a vote, take the sympathy of society when many of the people who are in doubt about the labeling of Islam in the party.
\end{abstract}

Keywords: Participation, Islamic, Political

\section{Introduction}

It is a fact that, in any Muslim-majority country have at least one party that carries the Islamic parties, irrespective of religion as a mere guise or pure fighting Islamic shariah. Call it like Party Brotherhood Muslimim in Egypt, PAS in Malaysia, PKS (Prosperous Justice Party), PKB (National Awakening Party), PBB (Crescent Star Party) in Indonesia and so on, so urging the election (running the government) more equitable, freely, without intervention and coercion of the party or political alliance in power (government Islamic Education).In 2010 the world was shocked late last large demonstration in Egypt's anti-government forced President Hosni Mubarak stepped down to prabon. Support this movement the greater when several ministers resigned and immediately join the unstoppable force it. Having traced behind the action is on the work of the Muslim Brotherhood party. The party refers to the Muslim Brotherhood movement founded in Isma'ilism in 1928 by Hasan al-Banna to spread Islam based on love, brotherhood and friendship (David Sagiv, 1995). Another case is also in Malaysia, for example, when PAS managed to seize some land parts such as Kedah and Terengganu in addition to Kelantan which was a stronghold of PAS (John L. Esposito and John O Voll, 1999), which was originally controlled by Barisan Nasional notebenenya is party coalition government the early days of the leadership of Abdullah Ahmad Badawi. Similarly in Indonesia, several Islamic parties showed ascending trend in the pan sound. It is understood of course that the issues that brought the party is a central issue in the community that directly touches people's hearts and minds. 
Not a secret that, Islamic parties less or even no place in the political dynamics because it gives a chance to not get a big influence. Is feared to be a butcher's ruling party. Islamic Party is simply used as a rice added in a dish that is already complete and perfect, to say democracy. Nevertheless, the existence of the Islamic party still pushed to the surface. He always shows his contribution to compensate for the various forms of injustice, by bringing their ideology.

According Sukron Kamil, it is based on two things: the first, elite religious authorities be set only in the spiritual field and even in some cases only a tool to justify the interests of the authorities. Second, the religious rules governing public affairs such as criminal law is not being enforced civil law more run (Sukron Kamil, 2002). In addition Islamist party also intends to seize the reins of government to the strategy of flexible ideology, not closed to other religions. Ideology does not become urgent because Islam does give leeway, so in practice we see many Islamic parties in alliance with the opposite party ideology with them such as Hezbollah in Lebanon, allied with the Maronite Christian leader, Michel Aoun. Socialist parties and the communists allied with Muslim governments, Fouad Seniora. Islamic congregation on one side of the alliance with secular groups against the regime of Ziaul-Haq despite their initial motive is aggressive Islamization policies. Similarly, in Jordan, the Islamic Action Front (IAF) and Yemen cooperate with the parties of various ideological spectrum, including communists and socialists to fight injustice rulers of their countries that restrict freedom of elections (Abdulkader H. Sinno and ahmed Khanani, 2009). Egypt's Muslim Brotherhood allied with the liberal, leftist and Arab nationalist government of Hosni Mubarak to curb the authoritarian and wanting to be president for life like in Libya.

This is a strength of Islamic parties still exist. Ideological flexibility is not surprising as the building blocks of theology from the Qur'an and Sunnah that are relevant for developing political participation in democracy. There is an assumption angled towards the participation of Muslims that want to tear down the building of democracy that has been built firmly in the minds of everyone. Though Islam since dirisalahkan to the Prophet Muhammad, has put a lot of life by promoting the values of Islam, one of which is democracy. So in this case was not entirely true though there are some known cases, but it can not necessarily be generalized to all parties to Islam. As mentioned above, this is probably the party of Islam as their symbol when in fact not the case.

\section{Participation Islamic Party}

Political participation is an activity a person or group of people to participate actively in political life by choosing the country's leaders and directly or indirectly influencing government policy. Political participation such action is to do with the vote in the election, attended the rally, a member of the party, to make contact with government officials or parliamentarians (Miriam Budiardjo, 1998). Political participation can be identified throughout the process of interaction between people and the organizers of the country and for the people involved in the process of influencing public policy. The process was shown to an influence and affect each other (Ali Anwar, 2004).

Political participation can be done individually or collectively, organized or spontaneous, steady or sporadic, legal and illegal, effective and ineffective. In practice, these forms will depend on the resources owned by the perpetrators, and it depends on the political situation of the country is being underway. The thinking underlying the concept of political participation lies in understanding that sovereignty is in the hands of people that should be implemented through joint activities to establish objectives and determine the people who will hold the reins of leadership (Ali Anwar, 2004). Political participation is one dimension of the political 
stability of a society or a nation-state, while the other dimension is the economic development and political institutionalization. The higher the participation, the better the political institutionalization and growth, as well as fairness in the better economic development political stability. Conversely, when these variables low will encourage instability in politics (Ali Anwar, 2004).

Muslim political participation does not have to be formal but can be substantial. That is, the universal values of Islam is entitled to fight for the Muslims rather than symbols of Islam that is not accepted by a wide audience, especially among non-Muslims and nationalists in general. The struggle to uphold the universal values of Islam such as justice and human rights, consultation, equality, tolerance, and the public good, can only be supported by the political participation of Muslims who understand the values of the plurality of groups of people in a religion other than ethnicity, language, social class, and gender. Muslims toughest challenge thus is how to respond to pluralism, long Muslims are in the framework of the nation-state, during the same respect for the plurality should not be lost and democracy has the right to life of individuals and communities of different religions (A. Ezzati, 1990),

\section{Islamic Party in Muslim Countries}

According to Ira M. Lapidus, modern Muslim society is divided into two types: a secular and Islamic Neo (Ira M. Lapidus, 1999). Secular Muslim countries are Muslim countries that make Islam no longer play a role in public life, which therefore religious elites subordinated under the political elite. The prevailing political system is pluralistic secular political system in which religion and country walks in the dialectic masuig each (Sukron Kamil, 2002). Average neo Islam is grounded in a comprehensive Islamic teachings to modern life, either public or private. Therefore, for the safety of life, Islam should be executed totalistic (kaffah). Given Islam set about politics, then it must be raised at political region (Sukron Kamil, 2002).

In general, in the Muslim countries shut secular political Islamic movements or Islamist parties. They apply a policy of one party or single party with the support of the military. Egypt, for example, be a military regime in power after a coup in 1952 that was led by military officers. Like Gamal Abdul Nasser, Anwar Sadat and Hosni Mubarak. Similarly, in Iraq, when Saddam Hussein in power, the military as its main strength and makes the Baath Socialist Party as a single party. In Syria, Hafez al-Assad in power, a military elite that came to power after a bloodless military coup in 1971 with the National Front progressive. This front is a combination of the Baath Party and four groups outside the Baath. Similarly, in T'urki and North Africa. In Turkey, the military regime frequent political intervention. In North Africa, namely Algeria and Tunisia's ruling is a single party. Algerian Front de Liberation National (FLN) and Tunisian Constitutional Democratic Unity Party / RCD. Being in Morocco, apply the monarchy with the king Hasannya. All three were oriented to the French and political elites as well prancis. Malaysia ruling party in the ruling coalition led by UMNO (Sukron Kamil, 2002).

But in other Muslim countries, there is a pretty interesting dynamic. Jordan, for example, accept the Islamic party. Others reject explicitly as Algeria. Case warmest is the accommodating attitude Jordanian government on the one hand and on the other side of the case of the FIS in Algeria. When in Jordan, Muslim Brotherhood always have a place in the government and given the trust holds five ministerial posts, the opposite happens in Algeria. In one of the Maghreb countries, the reforms carried out Benjedid 1989, which deletes a single-party socialist tradition Algeria and subsequently applied multi-party political system, but it did not last long. Front Islamique du Salut (FIS) Islamic party coalition under the leadership of Sheikh Ali Abbas Madam, a professor moderate, which won elections in 1991 and 1992, then 
disbanded and banned. The party utilizing the alienation of the Algerian people in the middle of the application of the French cultural and economic failure of the government to call for a return to the authenticity of the movement of Arabization and Islamization. The party leaders criticized Westernization, Western democratic practices at the expense of social and economic justice and considers solving problems by imitating western Algeria as a museum that is not capable of confronting a crisis and example to as neocolonialism. In a situation where unemployment is severe and uneven economic distribution, FIS support of the poor and the middle class (Sukron Kamil, 2002). Since the FIS split into two factions; moderate and militant. The latter has now made guerrilla warfare (John L. Esposito and John O Voll, 1999).

The views and attitudes shown the military and secular elite elite Algeria as above is not only applicable in the country. However, the case also in Tunisia. Tunisia, as in Algeria, secular elites in power see the Islamic political movement is not just a threat to hegomoninya, but if allowed will be the victory of fundamentalism that threatens the liberalization and democratization. Given such a view backed by the West, they dared to take actions that actually counter democracy (Sukron Kamil, 2002). Call it for example, the regime of Ben Ali, who took over the reins of power from Bourqiba, November 1987, although it has done political liberalization, does not acknowledge the Islamic Renaissance Party (al-Nahdhah) as an official party. Party, previously called the Islamic Tendency Movement (Movement de Tendence Islamigue / MTI) is led by Ghannausyi. The reason Ben Ali, because this party has confuse religion and politics. Consequently then, confrontation was inevitable. Renaissance Party leaders were imprisoned and tortured. Ben Ali's liberalization program, although the party had previously been allowed to publish a journal or newspaper, proved to be deviated from the spirit of democracy. Islamic Renaissance Party finally and Ben Ali's party, the Union of Constitutional Democracy, cheated in the elections of 1989. True democracy and freedom of the press in this country, there is no (Sukron Kamil, 2002).

The situation is more tragic, happened in Syria and Iraq. In Syria, the opposition Muslim "fundamentalists" who reject the ideology of secular Baathism Asad always put down with violence. In 1980, for example, in Aleppo, about 30 members of the Muslim Brotherhood sentenced to death and another 6,000 went to prison. Two years later they managed to consolidate Hamma occupied the city in February 1982 to establish Islamic rule. They then swept by one of the elite Syrian troops Sarayadifa '. About 20,000 members of the Muslim Brotherhood Hamma in the tragedy of the doomed. As in Syria, Iraqi opposition movement against Saddam Hussein's iron hand always be silenced with violence, and the opposition always fail, although the latter supported by the United States. Notably the Kurdish opposition were answered Saddam with chemical weapons of mass destruction (Sukron Kamil, 2002). Another case also in neo-Islamic countries such as Pakistan, Iran, Sudan, and Libya. Islamic parties showed varied dynamics. Pakistan since under the leadership of Zia Ul-Haq (19771988), making Pakistan as the country more conservative Islamic-oriented. It performs the steps Islamization of the state and society as well as the full support of Islamic parties, especially its Jama'ah Islamiyah Maududi (Sukron Kamil, 2002). Furthermore, he was replaced by Benazir Butho more nationalist. But did not last long because it was unable to stem the dominance of Islamic party of Nawaz Sharif followed by Pervez Musharraf.

Iran, after the death of Imam Khomeini as a revolutionary leader in June 1987, faced with a conflict between the Mullah Hasyemi moderates led by Rafsanjani and the Mullah radicals led by Ali Khameinei. For moderate and pragmatic Rafsanjani, the restructuring of the national economy must take precedence over the attitudes of the revolution. As a moderate, he also sees the need to normalize relations with the West. The moderate view, followed by President 
Khatami. In fact, he had recommended the establishment of a new party in addition to a singleparty government. He who backed moderate technocrats, presumably, wants to bring Iran to a more open country and appreciate diversity (Sukron Kamil, 2002). But when Mahmoud Ahmadinejad took office, the West embrace policies that actually left.

Sudan currently led by Umar Hasan al-Bashir as the regime showed its orientation towards Islam. It utilizes party people NIF (National Islamic Front) and Islamic parties formed the Muslim Brotherhood under the leadership of Hasan Turabi. NIF many people who occupy important positions and between Turabi was Bashir with intricate interwoven relationships in which even if Turabi does not have an official kedududukan in government, but became the guiding ideology for the regime. At this time began the Islamization of government (Sukron Kamil, 2002).

Libya under Muammar Qaddafi showed his leadership style tends to radical Islam. He combines a model of Arab nationalism and socialism with Islamic fundamentalism as a strategy to gain support from voters (Sukron Kamil, 2002). What can be understood from this type of state is the view of elites who see the country and government policies as the representative of God's sacred and absolute. Consequently, there is no more room for difference, criticism, much less rejection. Disagreements with the leadership of the country is tantamount to opposing God. Therefore, freedom of speech, the opposition will hardly be expected to be born (Sukron Kamil, 2002).

\section{Islamic Party in Indonesia}

Throughout its history after independence on August 17, 1945, Indonesia has carried out 8 elections. From all these elections never miss followed by Islamic parties (Hamdan Zoelva). The first election was held on September 29, 1955, followed by five Islamic parties, namely the Assembly Suro Muslimin Indonesia (Matsyumi), Nahdlatul Ulama (NU), Partai Syarikat Islam Indonesia (PSII), Party Tharekat Islam Indonesia (PTII), Association of MT Islamiyah ( Perti) (Mukhamad Shokheh, 2008). The result is quite good, although it is still inferior to secular nationalist parties.

The most outstanding political issues brought by the Islamic parties' election results in 1955 and they have the same sound to it, is a matter of ideology that is Islam as the state, faced with another group who want Pancasila as well as socio-economic foundations of the State. It happened because at the time it was being debated on the Indonesian Constitution in the Constituent Assembly. But the debate about the basic State does not produce results because the strength of Islam and Nationalists have a balanced force. At that time the whole Islamic party considers that Islam and politics are inseparable and politics is part of the law. In the next election, the participation of Islamic parties is relatively stable in the sense not much different from the first election, the beginning is followed by five Islamic parties, was the second election of the four parties followed by a vote of $26.5 \%$. After that level of sensitivity and public confidence in the Islamic party is decaying (Hamdan Zoelva, 2003).

In the post-New Order elections, Islamic parties are involved in the democratic party there are eight parties. The results showed a very minimal when compared with the vote political party which is not based on Islam. United Development Party which has been almost a quartercentury gained only 58 seats in the House that is $12.6 \%$ of the 462 contested seats. Crescent Star Party gained 13 seats, or 2\%, the Justice Party gained 7 seats, or 1.5\%, Nahdlatul Ummah Party gained five seats or 1\%, and three other Islamic parties that earn seat 1 seat respectively, the Ummat Awakening Party, Syarikat Islam Party and Party 3 seats Matsyumi thus amounted 
to $0.64 \%$. Meanwhile, the second mass-based Islamic party, gained a seat that was also not so great, that the National Awakening Party gained 51 seats or $11 \%$ and the National Mandate Party gained 34 seats or $7.36 \%$. So the total number of seats the two parties was 85 seats or $18.36 \%$. This amount is balanced with the number of seats of Islamic parties. While the total number of seats the party based Islamic parties and Islamic mass is 171 seats, or $37 \%$. The role and position of parliamentary election results in 1999, occupies a strategic position for the future of Indonesia, because in this period the strategic policies and fundamental for the future of Indonesia is put among others, with the huge changes in the Constitution of the Republic Indonesia (Hamdan Zoelva, 2003). In the 1999 elections, the general map of power Islamic parties according to Taha Idris, is two traditional Islamic Party represented nahdhiyin or PKB which is the official party of NU. The second Islamic party Modernist divided into two: conservative and liberal. Conservative modernist Islamic groups joined the political parties that carry Islam as the ideological basis. Such as PPP, PBB, PK. And many liberal modernist Islamic groups to join in the party Golkar and PAN (Taha Idris, 2005).

The interesting thing is observed that the views and position of Islamic parties and parties based Islamic masses differing views in the debate on article 29 of the 1945 Constitution of Islamic Parties led by the Crescent Star Party and the United Development Party (M. Rusli Karim, 1985) proposed the addition of seven words of the Jakarta Charter. On the other hand this proposal did not gain the support of both mass-based Islamic party in the Assembly. This is understandable because both parties claim to be open and inclusive party. Very different from the position konstiante debate in the 1955 election results, in which all Islamic parties fight for Islam as the basis for the State, both of NU who sit in the Assembly as well as on the basis of Muhammadiyah as an outstanding member Masjumi. There is an interesting case of a party traditionalist NU NU (Greg Fealy, 2004) despite the political elite at odds with each other, but can generally be described that this party is directed to develop themselves in the mainstream of political accommodation. Many political elite is seen as too accommodating to the authorities to obtain political positions that are not too decisive and control over the bureaucracy at the Ministry of Religious Affairs, an agency that provides financial security for its members. Because this is often labeled the party the party of opportunism (Bahtiar Effendy, 1998).

These developments indicate a significant change in the perspective of Islamic politicians about the relationship between the state with religion (Islam). As evidence, for example, elite political parties in NU no longer spit political role as the only way to convey the message of religion, but rather to how the welfare of the people. There is an effort to create conditions more favorable than bragging society about political Islam Ali Anwar, 2004). On the other hand, when it comes to practical politics in terms of determination and leadership elections, Islamic parties and Islamic mass-based parties can come together and have the same view. It can be seen at the time of the election of President Abdurrahman Wahid at the General Session of 1999. This is also evident in the political process and the various decision-making regarding the determination of public officials by the Parliament, it is almost certain that these parties can come together and have the same view, this shows the attitude pragmatism Islamic politicians in parliament in politics.

Another thing to note for the Islamic parties could reoccupy the position ever achieved at the 1955 general election is to do an evaluation and reconstruction of the strategy launched at the elections they had done in order to get the core issue in the decline in sound so great. Opportunities for Islamic parties is the shift in voter choice before choosing PDIP and Golkar Party, as well as of the voters. It can only be achieved by the ability of the internal consolidation 
of Islamic parties in order to organize, mobilize the, formulate and express the interests of Muslims better. Political jargon flow and ideology still worth voiced by Islamic parties in addition to offering programs better and to touch people's interests are widely (Hamdan Zoelva, 2003).

\section{Conclusions}

However, the existance Islamic parties in the political arena has its own color and its variants and takes place within the framework of the existing state system. Regardless of which group or who refuse to accept their presence, still counts. At least as imaging of the countries concerned, that the Islamic party is not muzzled and showed the democratization process in the country. The Muslim Brotherhood, founded by Hasan al-Banna in Egypt is very different from the Muslim Brotherhood in other places, such as in Sudan and Syria. Similarly, Islamic Jamaat Maulana Maududi participation of Pakistan differ from those in Bangladesh, Afghanistan and others. But clearly demonstrated that participation of Islamic parties seen in Iran and Sudan who managed to establish a state with the strength and support of Islamic parties. Egypt and Algeria, the Islamic party is always under pressure and depressed from the government even considered illegal movement, but continues to struggle in order to gain legitimacy from the state. Very different to Malaysia, Pakistan (John L. Esposito and John O Voll, 1999), and Indonesia, where Islamic parties play a role as a counterweight to the ruling power and mutually complementary in the government system in the country.

\section{References}

Anwar, Ali, Avonturisme NU : Menjejaki Akar Konflik Kepentingan-Politik Kaum Nahdhiyyin, Bandung : Humaniora, 2004

Budiarjo, Miriam, Partisipasi Dan Partai Politik, Jakarta : Obor, 1998

Effendy, Bahtiar, Islam dan Negara : Transformasi Pemikiran Dan Praktik Politik Islam Di Indonesia, terj. Ihsan Ali Fauzi, Jakarta : Paramadina, 1998

Esposito, John L dan John O Voll, Demokrasi Di Negara-Negara Muslim, Problem Dan Prospek, terj. Rahmani Astuti, Bandung : Mizan, 1999

Ezzati, A, Gerakan Islam, Sebuah Analisis, terj. Agung Sulistyadi, Jakarta : Pustaka Hidayah, 1990

Kamil, Sukron, Islam Dan Demokrasi, Telaah Konseptual Dan Historis, Jakarta : Gaya Media Pratama, 2002

Karim, M. Rusli, Dinamika Islam Di Indonesia, Suatu Tinjauan Sosial Dan Politik, Yogyakarta : Hanindita, 1985

Khallaf, Abdul wahab, Politik Hukum Islam, terj. Zainudin Adnan, Yogyakarta : Tiara Wacana Yogya, 1994

Lapidus, Ira M., Sejarah Sosial Ummat Islam, Jilid tiga, terj. Ghufron A. Mas'adi, Jakarta : Raja Grafindo Persada, 1999

Mujani, Saiful, Muslim Demokrat : Islam, Budaya Demokrasi Dan Partisipasi Politik Di Indonesia Pasca Orde Baru, Jakarta : Gramedia Pustaka Utama, 2007

Sagiv, David, Islam Otentisitas Liberalisme, terj. Yudian W. Asmin, Yogyakarta : LKiS, 1995

Shokheh, Mukhamad, Dari Konfrontasi Menuju Akomodasi, Relasi Islam - Negara Di Indonesia Masa Orde Baru 1966 - 1998, Semarang : UNNES, 2008

Sinno, Abdulkader $\mathrm{H}$ and ahmed Khanani, Of Opportunities And Organization, When Do Islammist Parties Choose To Compete Electorally? Dalam M.A. Mohamed Salih, (ed), Interpreting Islamic Political Parties, New York : Palgrave Macmillan, 2009

Thaha, Idris, Demokrasi Religius, Pemikiran Politik Nurcholish Madjid Dan Amien Rais, Jakarta : 2005 
Wahid, Marzuki, ( ed ), Jejak-Jejak Islam Politik, Sinopsis Sejumlah Studi Islam Indonesia, Jakarta : DITPERTAIS, 2004

Zoelva, Hamdan, Partai Politik Islam Dalam Peta Politik Indonesia, Dalam Diskusi The International Institute of Islamic Indonesia (IIIT), tanggal 17 April 2003. 